\title{
Physico-Chemical and Biological Assessment of Water Quality in Shihu Lake and Grand Canal, P.R. China
}

\section{Sisay Abebe Debela ${ }^{1,4 *}$, Magai Isaiah Barach ${ }^{2,4}$, Meklit Degu Berta ${ }^{3,4}$, Yinling Song ${ }^{4}$, Shushu Shen ${ }^{4}$ and Amana Ogeto Luke ${ }^{5}$}

${ }^{1}$ Ethiopian Environment and Forest Research Institute, Addis Ababa, Ethiopia ${ }^{2}$ College of Environmental Studies, Dr. John Garang Memorial University of Science and Technology, South Sudan

${ }^{3}$ Ministry of Urban Development, Housing and Construction, Addis Ababa, Ethiopia

${ }^{4}$ Suzhou University of Science and Technology, School of Environmental Science and Engineering, China

${ }^{5}$ Rift Valley University, School of Health Science, Abichu Campus, Ethopia

*Corresponding Author: Sisay Abebe Debela, Ethiopian Environment and Forest Research Institute, Addis Ababa, Ethiopia and Suzhou University of Science and Technology, School of Environmental Science and Engineering, China.

DOI: 10.31080/ASNH.2020.04.0633
Received: January 03, 2020

Published: February 06, 2020

(C) All rights are reserved by Sisay Abebe

Debela., et al.

\begin{abstract}
Water is most important in shaping the land and regulation of the climate. It is one of the most important compounds that profoundly influence life. The quality of water is usually described according to its physical, chemical and biological characteristics. Rapid industrialization and indiscriminate use of chemical fertilizers and pesticides in agriculture are causing heavy and varied level of pollution in aquatic environment leading to deterioration of water quality and depletion of aquatic biota. Due to use of contaminated water, human population suffers from water-borne diseases. It is therefore necessary to check the water quality status. The objective of this Assessment was to determine physio-chemical and biological status of Shihu Lake and Grand Canal. A sample was collected to determine the Dissolved oxygen and micro-organism in laboratory by using Winkler method and microscope respectively. Temperatures, PH and transparency of water were measured and evaluated on site at water bodies. The Dissolved Oxygen of the Grand Canal and Shihu Lake is $12 \mathrm{mg} / \mathrm{l}$ and $10.44 \mathrm{mg} / \mathrm{l}$ at depth of $35 \mathrm{~cm}$ and $25 \mathrm{~cm}$ respectively. Under the microscope different microbes were found like cyanobacteria, fiber algae and insects. The average of secchi disk of transparency is $55.5 \mathrm{~cm}$ and $59 \mathrm{~cm}$ respectively at Grand Canal and Shihu Lake. Constant temperature and $\mathrm{pH}$ were recorded at $20.0^{\circ} \mathrm{C}$ and $8.0 \mathrm{pH}$ for both Grand Canal and shihu Lake respectively. The waters content of both sites was in stable natural condition. The presence of few microorganisms and some organic substance is an indication that the water ecosystem is balance, but eutrophication can result as nutrient cycle and Algae continue to grow. The concerned bodies should continue to monitor and prevent entrance of untreated effluent to the water bodies as well as control of pollutants from nonpoint pollution sources.
\end{abstract}

Keywords: Physio-Chemical; Dissolved Oxygen; Microorganism

\section{Introduction}

Microscopic organisms, commonly known as microorganisms or microbes, are found everywhere. The category 'Microbes' includes a massive range of organisms including bacteria, fungi, viruses, algae, archaea and protozoa. The microbiological examination of water is used worldwide to monitor and control the quality and safety of various types of water. These include: potable waters (water intended for drinking or use in food preparation), treated recreational waters (swimming pools, spa pools, hydrotherapy pools), and untreated waters used for recreational purposes such sea, river and lakes water. Microbiological examination of water sample is usually undertaken to ensure that the water is safe to drink or bath in.

Many microorganisms play foundational roles in aquatic ecosystems, capturing the sun's energy through photosynthesis and, through their role in decomposition, releasing nutrients stored in organic tissue. Phytoplankton and bacteria have a greater effect on water quality than do other aquatic microorganisms. Phytoplanktons are the main primary producers while bacteria are responsible for the majority of organic matter decomposition and nutrient recycling. Water quality of rivers, natural lakes, and reservoirs in developing countries is being degraded because of the contaminated inflows [1-4]. 
With the rapid economic and social development in recent decades, non-point source pollution to the environment from livestock and poultry industry, aquaculture industry, planting industry, and rural domestic sewage to our living space centered on the Earth has drawn much attention to the public and policy-makers. Among various pollutions, water environmental pollution, as a vital threat to human being health, also became the most remarkable issue for the sustainable development.

This study discusses about both physical and microscopic observation of water samples from Grand Canal and Shihu Lake. The water samples was collected by plankton net for microscopic observation which will determine the quality of the water and also based on the parameters like transparency, dissolved oxygen, temperature and $\mathrm{pH}$ at different depth of the water on site physical measurement was done.

The results obtained in this study will be useful to identify pollution status within the lake and canal for further monitoring and better management. Since increasing urbanization and its impact on water bodies is a serious problem worldwide, the results reported here will be of general interest and relevance. Because, this water adds pollution to our food chain in addition to groundwater contamination when used to irrigate crops. These risks must be kept at a level acceptable to the community.

\section{Study area}

Suzhou is located in the south of Jiangsu province, some 50 miles west of Shanghai. The city has been famous for its gardens for many centuries. The city is dotted with lakes and ponds connected by a spider's web of canals. And all the canals are lined with whitewashed houses with gray-tiled roofs. It is a major economic center and focal point of trade and commerce, and the largest city in the province. Resting 13 feet ( $4 \mathrm{~m}$ ) above sea level, almost half of the 3,276-square-mile (8,488-sq-km) city of Suzhou is covered by water -42.5 percent to be exact - making it a top-ranking, water-rich Chinese destination.

Shihu lake is Located in the outskirts of Suzhou city. There is a mountain by the lake covered with virgin forests. Shihu is a shallow lake.

The Suzhou Grand Canal is located at the Taihu Lake Basin in the downstream of Yangtze River and belongs to Jiangnan Grand Canal which starts from Zhenjiang in the north and ends at Hangzhou in the south, and it's an important part of Beijing-Hangzhou Grand Canal. The Grand Canal is one of China's most magnificent and astounding creations. Approximately 1,200 miles (1,776 km) from tip-to-tip, the Grand Canal is the longest man-made waterway in the world. Officially known as the Beijing-Hangzhou Grand Canal, its route runs from Beijing in the north to Hangzhou in the south, connecting to various river systems along the way. The entire Grand Canal has been declared a UNESCO World Heritage Site [5].

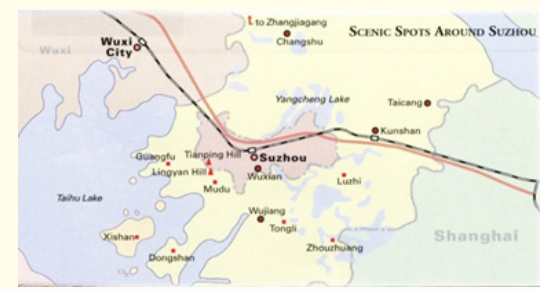

Figure 1: The map of Suzhou city, source google scholar.

\section{Methodology and Materials}

Water sampling procedure and physical measurements

Microscopic examination of collected water sample was done. The water samples were collected from two sites. The first sample was collected from Grand Canal water and the second from Lake of Shihu for microbial observation and determination of dissolved oxygen in the laboratory by using Winkler techniques [6]. Other parameters were measured on site at the water bodies. The assessed parameters on site were physical water quality measurements.

\section{Water sampling}

For both water sources samples were collected by sweeping the plankton net through the water around 10 times and, water sample was collected in to brown bottle.

\section{Materials}

Materials for water sampling and on site measurement

- Plankton net

- Litmus Paper

- Measuring Tape

- $\quad$ Plastic Bag

- Brown Bottle

- $\quad$ Secchi disk

- $\quad$ Brown Lab Bottle.

Materials for laboratory microbial observation

\section{- Microscope}

- Microscopic slides

- Cover slips

- Pipette/dropper

- $\quad$ Slide tissue.

Apparatus and reagents used for DO determination Apparatus

- Capacity bottle with stopper,

- Pipettes

- Burette

- Stand

- Measuring cylinder and conical flask

- Dropper. 


\section{Reagents}

- $1 \mathrm{~mL}$ Manganese Sulfate $\left(\mathrm{MnSO}_{4}\right)$ solution

- $2 \mathrm{~mL}$ Potassium iodide (KI) solution

- $2 \mathrm{~mL}$ Sulfuric acid $\left(\mathrm{H}_{2} \mathrm{SO}_{4}\right)$

- Sodium thiosulfate solution $\left(\mathrm{Na}_{2} \mathrm{~S}_{2} \mathrm{O}_{3}\right)$

- $1 \%$ Starch indicator.

Procedure for microbial observation

The water samples were prepared for microscopic observation in the laboratory, sampling and observation was done according to the following procedures:

- $\quad$ One drop of sample water was added to the slide from the brown bottle by using pipette,

- $\quad$ The slide were covered by the cover slip and put on the stage of the microscope.

- To observe a specimen the objective lenses were adjusted to $(40 \mathrm{x})$ to magnified the specimen 400 times (TMP of the microscope for that specimen $=$ objective lens $\mathrm{x}$ ocular lens),

- After that fine and coarse adjustments and light concentration was adjusted for clear observation.

- Totally, four samples two from each water source were observed for both water samples and different microbes were observed and the data was recorded.

Procedures for DO determination

Preparation of $0.001 \mathrm{M}$ sodium thiosulfate solution

- $\quad M$ of Sodium Thiosulfate Solution was added to $100 \mathrm{ml}$ distilled water and, then mixed until the solutes are completely dissolved or diluted.

\section{Procedure}

- $\quad 100 \mathrm{~mL}$ of the water samples were measured out to a 250 mL flask, and $1 \mathrm{~mL} \mathrm{MnSO}{ }_{4}$ solution and $2 \mathrm{~mL}$ alkali KI solution were added into the water sample. The mixture was capped with care. (Manganese hydroxide is a white precipitate; it's formation during reaction is the reason why a white precipitate is observed).

- The contents was mixed thoroughly by turning the bottle upside down around 10 times and kept for some minutes until the brown precipitate settled, the process was repeated again, and settled.

- $\quad$ After that $2 \mathrm{~mL}$ sulfuric acid were added and mixed by gentle inversion until dissolution is completed, and placed in a dark place for few minutes.

- The solution was titrated with sodium thiosulphate solution until the yellow color faded out (pale yellow color).

- Finally $1 \mathrm{~mL}$ starch indicator was added and the titration was continued until the end point (blue color turned to colorless) is reached and the volume of sodium thiosulphate solutions is recorded.

- After all, the same procedures above were repeated twice for each water sample and to find the total Dissolved 0xygen (DO), some calculations were done.
Transparency, temperature and $\mathrm{pH}$ analysis

Transparency of the water was measured at different depths by using secchi disk. Water temperature in shihu Lake and Grand Canal was measured at different depth by thermometer. In addition, the $\mathrm{pH}$ of the water was measured by using litmus paper.

\section{Results}

Transparency

The disk was lowered in to the water at different depths until the depth where black and white quadrants can no longer be seen from the surface is reached and the disk is pulled up slowly until it become. Depth measurement was done using a tape measure and the transparency at different depths was recorded.

\begin{tabular}{|l|c|c|c|}
\hline \multicolumn{4}{|c|}{ Grand canal water Transparency } \\
\hline Exp. No & Depth (cm) & Transparency level & Average of depths \\
\hline 1 & 35 & Visible & $55.5 \mathrm{~cm}$ \\
\hline 4 & 76 & Invisible & \\
\hline \multicolumn{3}{|c|}{ Shihu lake water Transparency } & \\
\hline 1 & 25 & Visible & $59 \mathrm{~cm}$ \\
\hline 4 & 93 & Invisible & \\
\hline
\end{tabular}

Table 1: The transparency of Shihu Lake and Grand Canal water at different depth, November 2017.

Water temperature at different depth

The water sampler that contain thermometer reading was submerged in to the water and pull out after some few minutes and, the temperature reading on thermometer was recorded This process was repeated four times at different depth to observe the temperature difference based on the Different depth. However, there was no change in temperature at different depth for both water bodies (Temperature remains constant at $20^{\circ} \mathrm{C}$ ).

\section{PH at different depth}

The water was dropped on the litmus paper and, then after few minutes the color changed and the $\mathrm{pH}$ was recorded according to the given $\mathrm{PH}$ value of Litmus color.

Temperature and pH measurement at different depth

\begin{tabular}{|c|c|c|c|}
\hline & \multicolumn{3}{|c|}{ Water sample from Grand canal } \\
\hline Exp. No & Depth $(\mathrm{cm})$ & Temperature $\left({ }^{\circ} \mathrm{C}\right)$ & $\mathrm{PH}$ \\
\hline 1 & 25 & 20 & 7 \\
\hline 2 & 55 & 20 & 8 \\
\hline 3 & 83 & 20 & 8 \\
\hline \multirow[t]{2}{*}{4} & 90 & 20 & 8 \\
\hline & Average & 20 & 8 \\
\hline \multicolumn{4}{|c|}{ Water sample from Shihu } \\
\hline Exp. No & Depth $(\mathrm{cm})$ & Temperature $\left({ }^{\circ} \mathrm{C}\right)$ & $\mathrm{PH}$ \\
\hline 1 & 25 & 20 & 7 \\
\hline 2 & 82 & 20 & 8 \\
\hline 3 & 104 & 20 & 8 \\
\hline \multirow[t]{2}{*}{4} & 117 & 20 & 8 \\
\hline & Average & 20 & 8 \\
\hline
\end{tabular}

Table 2: The PH of Grand Canal and shihu Lake at different depth. 


\section{Dissolved oxygen}

The collected water sample was analyzed after two days in laboratory by Winkler method. Winkler Method is a technique used to measure dissolved oxygen in water systems. The Dissolved Oxygen of the Grand Canal and Shihu Lake was measured, analyzed and recorded as $12 \mathrm{mg} / \mathrm{l}$ and $10.44 \mathrm{mg} / \mathrm{l}$ respectively.

\section{Microscopic observation of microorganism}

Under microscope the different microbes were found based on stock image [7], these include; cyanobacteria, fiber algae and insect like organism (spider like shape).

Four samples two from each water source were observed under the microscope the different microbes that observed under the microscope are lists as follow:

Microscopic observation for Shihu lake water sample

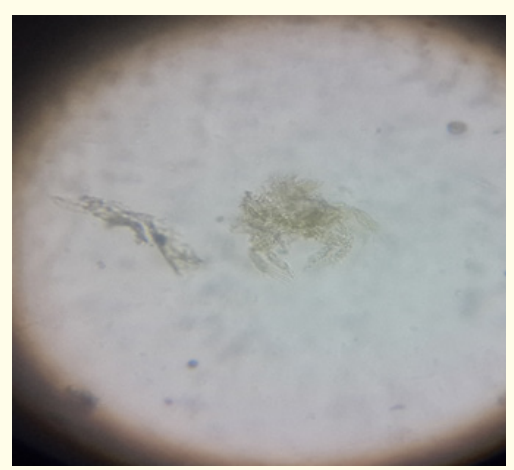

Figure 2: Animal like spider or insect (Source: Microscopic Result).

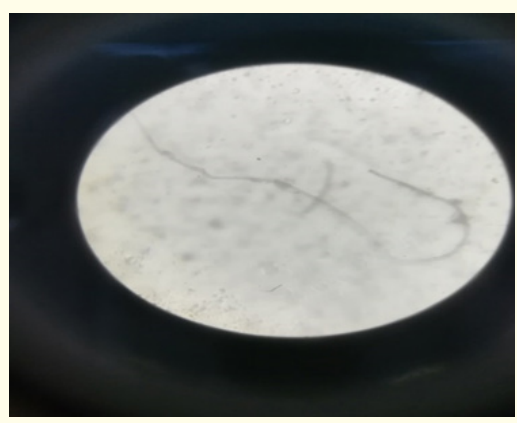

Figure 3: Screw bacteria (Source: Microscopic Result).

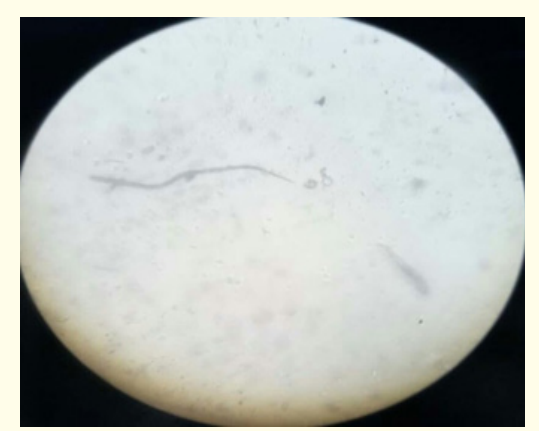

Figure 4: Fiber Algae (Source: Microscopic Result).
Microscopic observation for grand canal water sample

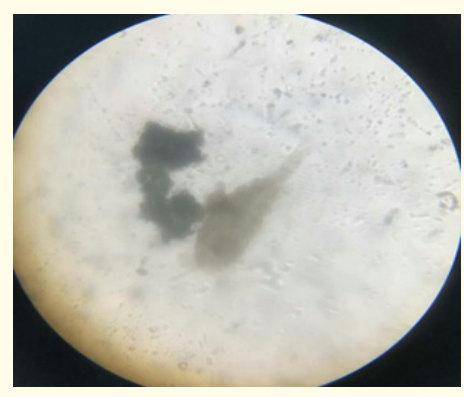

Figure 5: Cyanobacteria and some Animal (Source: Microscopic Result).

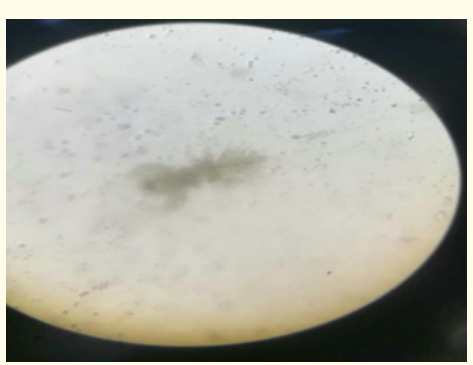

Figure 6: Insect (Source: Microscopic Result).

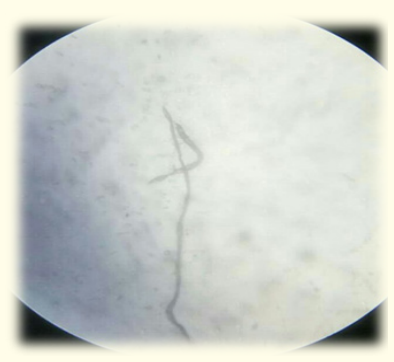

Figure 7: Fiber Algae (Source: Microscopic Result).

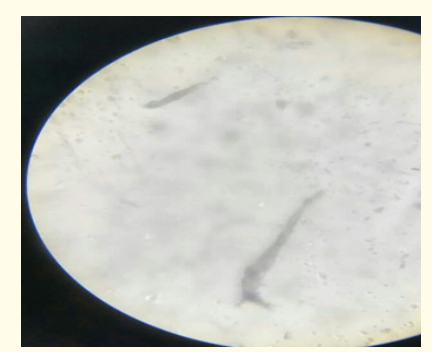

Figure 8: Fiber Algae (Source: Microscopic Result).

\section{Discussion}

Water temperature fluctuates between day and night, seasonally; it can also vary with depth. In lakes, temperature can vary with day and night and depth, according to the level of solar radiation penetration and mixing characteristics [8]. Temperatures are usually higher during the day than during the night. And usually higher during summer than during spring the temperature of surface 
water is usually between $0^{\circ} \mathrm{C}$ and $30^{\circ} \mathrm{C}$ [9]. The water temperature measured from both Shihu Lake and Grand Canal was constant at $20^{\circ} \mathrm{C}$. Under this temperature condition, the water is normal and safe for aquatic life. The amount of dissolved oxygen becomes lower as the water becomes warmer. Lower oxygen level of water a body can cause harm or death to the aquatic organisms that live there. It can also cause an increase in the photosynthetic rate of aquatic plants and algae. This can lead to increased plant growth and algal blooms, which can be harmful to the water ecosystem.

$\mathrm{PH}$ is a measure of the hydrogen ion $\mathrm{H}+\mathrm{H})$ concentration in water, and is commonly used to describe the acid/base balance of water. A pH of 7 represents neutral conditions, while $\mathrm{pH}$ values greater than 7 indicate basic (alkaline) conditions and $\mathrm{pH}$ values less than 7 indicate acidic conditions. The $\mathrm{pH}$ of the water measured at Both Grand Canal and Shihu Lake was around 7 and 8 respectively. The $\mathrm{pH}$ of most natural waters is between 6.0 and 8.5 [9]. Values of pH below 4.5 and above 9.5 are usually lethal to aquatic organisms, and even less extreme $\mathrm{pH}$ values can affect reproduction and other biological processes [11].

That is similar with most natural waters. So according to the data collected from the $\mathrm{pH}$ measurement Both Shihu Lake and Grand Canal water is fairly neutral and healthy.

Water transparency means how deep sunlight penetrates through the water. It depends on the amount of particles in the water. When the water is murky or cloudy and contains a lot of Available phytoplankton, suspended inorganic and dissolved matter, the light cannot penetrate as deeply as possible in to the water.

Transparency of the water at both water sources was measured by using the secchi disk. In Grand Canal water the disk was visible at the depth of $35 \mathrm{~cm}$ and totally disappeared at the level of $76 \mathrm{~cm}$. In Shihu Lake, the disk was visible at the depth of $25 \mathrm{~cm}$ and completely disappeared at a level of $93 \mathrm{~cm}$. The average of secchi disk is $55.5 \mathrm{~cm}$ and $59 \mathrm{~cm}$ respectively at Grand Canal and Shihu Lake. Different literature shows that if the average of secchi disk is below 2 meter the water is under eutrophication [12]. This result show that both water sources are under eutrophication.

The Dissolved Oxygen of the Grand Canal and Shihu Lake is 12 $\mathrm{mg} / \mathrm{l}$ and $10.44 \mathrm{mg} / \mathrm{l}$ respectively. These show that the Dissolved Oxygen (D.O) was not consumed by the aquatic microorganism and water is not polluted. The samples were collected at depth of $35 \mathrm{~cm}$ and $25 \mathrm{~cm}$ from Grand Canal and Shihu Lake respectively. The Grand Canal water at the depth of $35 \mathrm{~cm}$ the water was transparent and similarly the water at depth of $25 \mathrm{~cm}$ at Shihu Lake was transparent. This shows that the water is clean. The temperature and $\mathrm{PH}$ was recorded $20.0 \mathrm{oC}$ and $8.0 \mathrm{pH}$ for both Grand Canal and shihu Lake respectively. All parameters show that the water is in good natural state.

The first specimen observed from Grand Canal water sample was similar with the specimen of cyanobacteria that grow in colo- nies and some small animal were also observed (Figure 3 and 5). Cyanobacteria naturally present in small numbers in slow-moving fresh water bodies. However, when waterways become enriched with nutrients, rapid and explosive growths of cyanobacteria will occur. When algae grows too much it can form "blooms" which can cause various problems. It can lead to a depletion of oxygen in the water and a release of toxins, as well as taste and odor problems.

Insect and other animal were also observed in both sites (Figure 2 and 6). This shows that the water has low pollutant, and the water ecosystem is balanced.

In both water bodies the fiber algae was observed (Figure 4, 7 and 8). Algae in water bodies have its own merit and demerit. An excessive algae (Algae Bloom) is responsible for eutrophication in presence of nitrogen and phosphorous nutrients. Healthy Lake and other water bodies need algae. Algae are important to the productivity of water body. Algae are primary producers. They use sunlight (through photosynthesis) to produce carbohydrates and are eaten by grazers such as protozoa and zooplankton (little animals like water fleas and rotifers). The zooplanktons are, in turn, grazed upon by fish, which are eaten by bigger fish, and on up the food chain. A productive lake produces large fish and good for fishing as well as supporting food chain and habitat for wild life and water fowl.

\section{Conclusion}

The assessed parameters of physical, microscopic and chemical measurements show the absence of excessive organic pollutant in Shihu Lake and Grand water Canal. Therefore, the waters content of both sites is in stable natural condition. The Dissolved Oxygen of the Grand Canal and Shihu Lake is $12 \mathrm{mg} / \mathrm{L}$ and $10.44 \mathrm{mg} / \mathrm{L}$ respectively at the temperature of $20^{\circ} \mathrm{C}$, the measurement was done by Winkler techniques.

The presence of few microorganisms and some organic substance is an indication that the water ecosystem is balance, but eutrophication can result as nutrient cycle and Algae continue to grow.

\section{Bibliography}

1. Elisavet A., et al. "Physicochemical and microbiological characteristics of the potable water supply sources in the area of Kozani, Western Macedonia". Desalination 213 (2007): 1-8.

2. Niba RN and Chrysanthus N. "Bacteriological Analysis of Well Water Sources in the Bambui Student Residential Area". Journal of Water Resource and Protection 5 (2013): 1013-1017.

3. Desai JS. "Studies on Some Physico-Chemical and Microbiological Characteristic of Potable Water Used in Some Different Area of Ahmadabad in Gujarat". Der Chemica Sinica 3 (2012): 503-507.

4. Shrivastava N., et al. "Water Quality Deterioration of Machna River due to Sewage Disposal, Betul, Madhya Pradesh, India". Environmental Earth Sciences 3 (2013): 1-5. 
5. Sundar SB and Nirmala JK. "A Case Study on physico Chemical Properties of Ground Water in ID-Bollaram Industrial area, Hyderabad (India) during 2010 Monsoon to 2013 summer". Research Desk 4 (2015): 482-490.

6. The Winkler Titration method.

7. Royal free Microorganisms stock image in HD and millions of other royal free photos, illustration in Shutterstock collection.

8. Gupta V., et al. "Adsorption Analysis of Mn(VII) from Aqueous Medium by Natural Polymer Chitin and Chitosan". Asian Journal of Chemistry 20 (2008): 6195-6198.

9. Tahir MA., et al. "Method development for arsenic analysis by modification in spectrphotometric technique". Drinking Water Engineering and Science 1 (2008): 135-154.

10. Yadav SS., et al. "Monitoring Water quality of Kosi River in Rampur District, Uttar Pradesh, India". Advances in Applied Science Research 2 (2011): 197-201.

11. Diersing N. "Water Quality: Frequently Asked Questions PDA”. NOAA (2009).

12. APHA., et al. "Standard Methods for examination of water and wastewater". 22nd ed. Washington: American Public Health Association (2012): 1360.

\section{Assets from publication with us}

- Prompt Acknowledgement after receiving the article

- Thorough Double blinded peer review

- Rapid Publication

- Issue of Publication Certificate

- High visibility of your Published work

Website: https://www.actascientific.com/

Submit Article: https://www.actascientific.com/submission.php Email us: editor@actascientific.com

Contact us: +919182824667 